\title{
Biotechnological richness of the northeastern semi-arid region: antioxidant activity of casein hydrolysates from Moxotó goat milk (Capra hircus Linnaeus, 1758) obtained by papain action
}

Vilma Sobral BEZERRA ${ }^{1,3 *}$, Julia Furtado CAMPOS ${ }^{2}$, Roberto Afonso da SILVA ${ }^{3}$, Tatiana Souza PORTO ${ }^{4}$, José Luiz de LIMA FILHO ${ }^{3}$, Ana Lúcia Figueiredo PORTO ${ }^{1}$

\begin{abstract}
This study aimed to identify antioxidant peptides from caprine casein hydrolysates by papain application using MALDI-TOF mass spectrometer, and a $2^{2}$ full factorial design, with 4 axial points, in order to evaluate kinetic parameters (time and $\mathrm{pH}$ ) effects on the degree of hydrolysis as well as the antioxidant activity of Moxoto goat milk casein peptides. Degree of hydrolysis was determined by total and soluble protein ratio in casein. Antioxidant activity was measured by ABTS method with 2 , 2-cation-azinobis (3-ethylbenzothiazoline-6-sulfonic acid). TROLOX was used as standard. Peptide pattern and sequence of antioxidant amino acids were obtained using MALDI-TOF/MS. The highest degree of hydrolysis (28.5\%) and antioxidant activity (2329.6 mmol.L TROLOX. $\mathrm{mg}^{-1}$ peptide) were observed in the permeate. NENLL, NPWDQVK and LLYQEPVLGPV peptides, detected in the permeate, were pointed as the responsible for antioxidant activity, suggesting their potential application as food supplement and pharmaceutical products.
\end{abstract}

Keywords: bioactive peptides; caprine casein; antioxidant activity.

\section{Introduction}

In Brazil, the establishment of dairy goats is an important livestock activity for local economy, since these animals provide milk and meat, which are widely consumed by needy population (HAENLEIN, 2004). Moxotó goat is a caprine strain which arises from Moxotó Valley (Pernambuco State, Brazil). This breed is characterized by being prolific, resistant and easily adaptable to the semi-arid climate. Silva and Araújo (2000) pointed out that the exploitation of Moxoto caprine milk, in regards to human nutrition and milk derivatives production, is underexplored, although the utilization of goat milk peptides has an attractive potential in food industry. Caprine milk consumption is important owing to its beneficial nutritional characteristics such as large concentration of proteins with high $\mathrm{DH}$ nutritional value and potential use by people allergic to bovine milk (SANTILLO et al., 2009).

Casein is the main milk protein and represents $80 \%$ of total proteins (CLARK; SHERBON, 2000). It is inactive and latent in its primary sequence, requiring the action of proteolytic enzymes to release its active peptides (ROSSINI et al., 2009) In caprine milk, the observed proportions of this protein are: $\alpha_{s 1}$-casein 4 to $26 \%, \beta$-casein 42 to $64 \%$ and $\kappa$-casein 20 to $24 \%$ (CLARK; SHERBON, 2000).

In dairy and food industry, the use of proteolytic enzymes of animal, plant or microbial origin affects the final product of hydrolysis, which determines the type of bioactive peptide produced. One of these enzymes is papain, which is a cysteine protease of plant origin. Papain exhibits efficiency in milk proteins hydrolysis, acting on the hydrolysis of substrates containing lysine, arginine or valine residues. This enzyme is stable at high temperatures $\left(50-60^{\circ} \mathrm{C}\right)$ and its optimal $\mathrm{pH}$ values range from 6.0 to 7.5 (GHOSH, 2005).

Biological and functional properties of enzymatic hydrolysates of milk proteins can be improved by controlling kinetic conditions during proteolysis. Thereunto, the determination of $\mathrm{DH}$ degree of hydrolysis is essential. This is a quantitative parameter which represents the proportion of cleaved peptide bonds in relation to the total peptide bonds. Thus, DH can be used to compare hydrolysates with each other (BIASUTTI et al., 2008).

In studies conducted in different animal species, it has been reported that casein enzymatic hydrolysates exhibited different activities such as antithrombotic, antihypertensive, immunomodulatory, antioxidant, antibacterial, mineral carrier and hypocholesterolemic activities (LI; YOURAVONG; H-KITTIKUN, 2010; OLALLA et al., 2009). Nevertheless, in relation to Moxotó goat casein, no information of such activities was described. Some investigations concerning Moxotó goat are important since this goat breed has a high genetic variability which could indicate their potential as bioactive peptides producers (SILVA; ARAÚJO, 2000).

\footnotetext{
Received 19/2/2013

Accepted 16/6/2013 (006026)

Departamento de Morfologia e Fisiologia Animal, Universidade Federal Rural de Pernambuco - UFRPE, Recife, PE, Brasil

2 Laboratório de Nanotecnologia, Centro de Tecnologias Estratégicas do Nordeste - CETENE, Recife, PE, Brasil

3 Laboratório de Imunopatologia Keizo Asami, Universidade Federal de Pernambuco-UFPE, Av. Prof. Moraes Rêgo, s/n, Cidade Universitária, CEP 50670-901, Recife, PE,

Brasil,e-mail:villsb@yahoo.com.br

${ }^{4}$ Unidade Acadêmica de Garanhuns, Universidade Federal Rural de Pernambuco - UFRPE, Garanhuns, PE, Brasil

${ }^{*}$ Corresponding author
} 
Several techniques for evaluation, fractionation and identification of peptides obtained from protein hydrolysates have been investigated (CHICÓN et al., 2009; BIRKEMO et al., 2008). Among them, ultrafiltration followed by peptide pattern analysis by MALDI-TOF-MS $\backslash$ MS mass spectrometry are very advantageous techniques, once, its application reduces analysis time and analytical cost, allowing an accurate assessment of bioactive peptides (BIRKEMO et al., 2008).

This study aimed to determine the peptide pattern and antioxidant activity of peptides obtained from the hydrolysis of Moxotó goat milk casein by papain enzyme activity.

\section{Materials and methods}

\subsection{Material}

All samples of goat milk were collected from a purebred Moxotó animal, in the municipal district of Sertânia, Pernambuco State (Brazil). These samples were frozen, in liquid nitrogen, immediately after collection and kept at $-20^{\circ} \mathrm{C}$ until use. All reagents utilized in this study were of analytical grade.

\subsection{Caprine casein extraction}

Casein extraction was performed by isoelectric precipitation, at $\mathrm{pH} 4.6$, according to Egito et al. (2006), except for toluene removal. Casein precipitate was solubilized in $1 \mathrm{~mol} . \mathrm{L}^{-1} \mathrm{NaOH}$, $\mathrm{pH} 7.0$, and, subsequently, subjected to dialysis against deionized water at $4{ }^{\circ} \mathrm{C}$ for 96 hours. This product was lyophilized and stored at $-20^{\circ} \mathrm{C}$.

Lyophilized samples were resuspended in sodium phosphate buffer 0.1 mol. $\mathrm{L}^{-1}$, resulting in a $2 \%$ casein solution. They were subjected to hydrolysis using papain enzyme (EC. 3.4.22.2) (SIGMA-Aldrich St. Louis MO, USA), according to the variables established by a factorial design. After hydrolysis, samples were stirred for 30 seconds, followed by a $90{ }^{\circ} \mathrm{C}$ hot bath for 15 minutes, in order to inactivate papain enzyme. Afterwards, these samples were centrifuged at $12,000 \mathrm{x} . \mathrm{g}$ for 10 minutes and supernatants were used in both DH degree of hydrolysis determination and ultrafiltration treatment.

\subsection{Experimental design}

The effects of independent variables (time and enzyme: substrate ratio - E:S) on dependent variables (antioxidant activity and degree of hydrolysis - DH) were measured by a $2^{2}$ full factorial design, consisting of 4 factorial points (levels \pm 1 ), 2 central points (level 0 ) and 4 axial points $( \pm \alpha)$, totalizing 10 assays, according to Bruns, Scarminio and Neto Barros (2006). This study was carried out using a $50^{\circ} \mathrm{C}$ reaction temperature and $\mathrm{pH}$ 6.5, as established by Lira et al. (2010). The analyzed variables and their levels (obtained from the factorial design), which were used to obtain casein DH degree of hydrolysis as well as its antioxidant activity by papain enzyme utilization, are shown in Table 1. Statistical significance $(P<0.05)$ of data was calculated by Statistica 8.0 software (STATSOFT, 2008).

\subsection{Determination of caprine casein degree of hydrolysis (DH)}

This analysis was determined Casein DH determination by papain enzyme. It was performed as described by Centenaro, Prentice-Hernández and Salas-Mellado (2009) with modifications. DH was expressed according to the ratio between soluble and total protein concentrations (quantities). Soluble protein was determined as established in Lowry et al. (1951) method, using bovine serum albumin (BSA) (Sigma, St. Louis MO, USA) as protein standard. Kjeldahl method (Official Methods of Analysis of AOAC International (HORWITZ, 2000)) was employed in the determination of total protein.

\subsection{Separation of caprine casein hydrolysates by ultrafiltration}

Supernatants from casein hydrolysates with papain use were subjected to ultrafiltration through an AMICON membrane (Millipore, Canada), whose porosity (cut off) was $3000 \mathrm{Da}$. Afterwards, these hydrolysates were centrifuged at 12,000 x.g for 40 minutes, resulting in two protein fractions: peptides which is contained in the retentate $(>3000 \mathrm{Da})$ and in the permeate $(<3000 \mathrm{Da})$. Both were evaluated for antioxidant activity determination.

Table 1. Independent variables coded in accordance with studied levels for casein hydrolysis by papain use. Assays results for determining degree of hydrolysis (\% DH) and antioxidant activity of casein using papain enzyme, expressed as TEAC (TROLOX equivalent).

\begin{tabular}{|c|c|c|c|c|c|c|c|c|}
\hline \multirow{2}{*}{ Assays } & \multicolumn{2}{|c|}{ Coded Level } & \multicolumn{2}{|c|}{ Uncoded Level } & \multirow{2}{*}{$\mathrm{DH} \%$} & \multicolumn{3}{|c|}{ TEAC ( $\mu$ mol.L L $^{-1}$ TROLOX/mg peptide $)$} \\
\hline & E:S & Time $(\mathrm{h})$ & E:S & Time (h) & & Pool & $<3000 \mathrm{Da}$ & $>3000 \mathrm{Da}$ \\
\hline 1 & - & - & $1: 200$ & 3.0 & 17.4 & 882.4 & 349.2 & 418.1 \\
\hline 2 & - & + & $1: 200$ & 7.0 & 18.9 & 913.2 & 522.73 & 482.9 \\
\hline 3 & + & - & $1: 100$ & 3.0 & 3.2 & 1574.8 & 347.2 & 335.2 \\
\hline 4 & + & + & $1: 100$ & 7.0 & 18.5 & 1883.2 & 865.1 & 1231.6 \\
\hline 5 & -1.41 & 0 & $1: 220$ & 5.0 & 25.0 & 1434.6 & 1002.1 & 634.9 \\
\hline 6 & +1.41 & 0 & $1: 80$ & 5.0 & 27.2 & 1366.8 & 1101.0 & 1407.9 \\
\hline 7 & 0 & -1.41 & $1: 150$ & 2.2 & 12.3 & 1101.3 & 678.9 & 890.5 \\
\hline 8 & 0 & +1.41 & $1: 150$ & 7.8 & 22.1 & 996.9 & 881.7 & 789.6 \\
\hline 9 & 0 & 0 & $1: 150$ & 5.0 & 28.3 & 1674.2 & 2338.5 & 2030.9 \\
\hline 10 & 0 & 0 & $1: 150$ & 5.0 & 28.5 & 1580.5 & 2329.6 & 1967.5 \\
\hline
\end{tabular}




\subsection{Antioxidant activity of caprine casein hydrolysates}

The antioxidant activity of caprine casein hydrolysates was determined using ABTS+ [2, 2'-azino-bis (3-ethylbenzthiazoline6-sulphonic acid)] radical as described in Re et al. (1998). ABTS was dissolved in ethanol (Merck, Germany) to a concentration of $7 \mathrm{mmol} . \mathrm{L}^{-1}$. Oxidation reaction was carried out using $2.45 \mathrm{mmol} . \mathrm{L}^{-1}$ potassium persulfate under dark conditions for 16 hours. Hydrolysates [peptide pool, which was made up of a mixture of permeate $(<3000 \mathrm{Da})$ and retentate $(>3000 \mathrm{Da})]$, which were diluted for concentrations varying from 0.01 to $0.8 \mathrm{mg} \cdot \mathrm{mL}^{-1}$ peptide, were used to determine antioxidant activity. The reaction consisted of $30 \mu \mathrm{L}$ of peptide sample and $3 \mathrm{~mL} \mathrm{ABTS}+$ radical. Absorbance measurement $(734 \mathrm{~nm})$ was carried out in a spectrophotometer (Micronal, B582 model, São Paulo, Brazil) 6 minutes after reaction beginning. TROLOX (6-hydroxy-2, 5, 7, 8-tetramethylchroman-2-carboxylic acid) was used as reference standard. The percentage of inhibition was calculated as the concentration of antioxidants and TROLOX, which was determined as TROLOX equivalent antioxidant capacity (TEAC) at $\mu \mathrm{mol} . \mathrm{L}^{-1} \mathrm{TROLOX} . \mathrm{mg}^{-1}$ of peptide.

\subsection{Sequencing and profile of permeate ( $<3000 \mathrm{Da})$ and retentate (>3000Da) peptides obtained by MALDI -TOF MS $\backslash M S$}

Peptide pattern, using papain, was determined by MALDITOF- MS $\backslash$ MS mass spectrometry for permeate $(<3000 \mathrm{Da})$ and retentate $(>3000 \mathrm{Da})$ samples which presented higher DH degree of hydrolysis values as well as antioxidant activities. The matrix used in these experiments was alpha-cyano-4-hydroxycinnamic acid in $33 \%$ acetonitrile and $0.1 \%$ trifluoroacetic acid. It was used an Auto Flex III (Bruker Daltonics Inc., USA) to a mass range of 0.5 to $3 \mathrm{kDa}$ permeate $(<3000 \mathrm{Da})$ peptides and 1000 to $10,000 \mathrm{KDa}$ for retentate $(>3000 \mathrm{Da})$ peptides. Mass spectrometer calibration was established using a standard peptide mixture (Peptidemix-Bruker Daltonics Inc, USA). Amino acid - y and -b sequences were obtained by peptide fragmentation and analyzed by Flex Analysis-BRUKER Daltonics Inc. (USA). These amino acids sequences were compared with others available at NCBIBlast in order to confirm the obtained peptides.

\section{Results and discussion}

\subsection{Enzymatic hydrolysis of caprine casein by papain enzyme}

The influence of both reaction time and E:S ratio on the increase of goat casein $\mathrm{DH}$ degree of hydrolysis and its antioxidant activity by papain use is described in Table 2 . The statistical model used in our study included 2 main effects and 1 interaction between these effects. A confidence level of $95 \%$ was used in our analysis.

Both investigated variables influenced $\mathrm{DH}$, exhibiting significant effects on reaction time and E:S ratio. Linear time had a positive effect on $\mathrm{DH}$, which suggested that the longer time levels are, the higher casein $\mathrm{DH}$ degree of hydrolysis. However, E: S (Q) ratio had a significant negative effect on $\mathrm{DH}$ under tested conditions, which indicates that the decrease in E: S ratio from 1:100 to 1:200 favored $\mathrm{DH}$. Our results corroborate Lira et al. (2010), who demonstrated the influence of kinetic parameters in casein hydrolysis of Moxotó goat milk, by utilization of papain use, as well as the negative influence of E:S on goat casein DH. On the other hand, this situation was different when the E: S ratio decreased from 1:150 to 1:200, showing that intermediate levels were responsible for the greatest DH. It is noteworthy that quadratic time had the most significant effect on $\mathrm{DH}$, suggesting that a reduction in reaction time favors an increase in this parameter. The interactions between these factors, however, were positive.

The results of DH degree of hydrolysis for goat casein by utilization of papain are shown in Table 1 . The best DH degree of hydrolysis value, obtained in assay 10, was $28.5 \%$, using 1:150 E:S ratio for 5 hours. Our results confirm those of Lira et al. (2010), who obtained $28.18 \% \mathrm{DH}$ by goat casein hydrolysis with papain, using the same conditions tested in our study. From another standpoint, Zhang, Li and Zho (2009) obtained 10.2\% for DH when used papain enzyme to hydrolyze bovine casein ( $\mathrm{pH} 7.0$; 1:100 E:S ratio; $55^{\circ} \mathrm{C} ; 24$ hours), which was statistically different from our results. Zhao, Wu and $\mathrm{Li}$ (2010) detected values up to $32.45 \%$ for $\mathrm{DH}$ when bovine casein was hydrolyzed by papain for 4 hours. The increase in $\mathrm{DH}$ maximizes the production of hydrolysates containing free amino acids or small peptides,

Table 2. Main effects and interactions of time and E:S (statistically significant), degree of hydrolysis (DH) and antioxidant activity in caprine casein hydrolysates.

\begin{tabular}{ccccr}
\hline \multirow{2}{*}{ Factor } & \multicolumn{3}{c}{ Efect } & \\
\cline { 2 - 5 } & DH & TEAC $($ Pool $)$ & TEAC $(<3000 \mathrm{Da})$ & TEAC $(>3000 \mathrm{Da})$ \\
\hline (1)E:S (L) & -28.72 & $8.36^{*}$ & 26.98 & 13.87 \\
$(2)$ Time (Q) & -111.69 & $-8.62^{*}$ & -297.48 & -31.38 \\
E:S (Q) & -44.41 & $-2.94^{*}$ & -251.40 & -27.06 \\
Time (L) & 76.65 & $1.02^{*}$ & 54.96 & $6.45^{\star}$ \\
1(L) X 2(L) & 48.79 & $2.09^{*}$ & 27.36 & $9.28^{\star}$ \\
\hline
\end{tabular}

${ }^{*}$ Non-significant. TEAC: antioxidant activity ( $\mu$ mol TROLOX/mg protein). 
which represents an important factor for the production of protein hydrolysates with biological activity (SHOU-WEI et al., 2008; CHATAUD; DESREUMEUX; CARTWRIGHT, 1988). Nevertheless, an extensive hydrolysis may be harmful because it can lead to loss of peptide biological activities, due to the production of hydrolysates (free amino acids or small peptides) incapable of forming the chemical interactions which make them bioactive (SILVA; PIHLANTO; MALCATA, 2006).

In order to stimulate the growth of microorganisms cultures present in the milk protein hydrolysate, Zhang, Li and Zho (2009) performed a bovine casein hydrolysis by papain enzyme for the following conditions: 1:100, E:S ratio, $55^{\circ} \mathrm{C}, \mathrm{pH} 7.0$ and reaction time up to 24 hours. Additionally, Cavalli et al. (2008) reported that sodium caseinate digestion from goat milk, which was hydrolyzed by Staphylococcus marianum enzymes (extract at $\mathrm{pH} 6.5$, after 1 hour digestion), became intense as the reaction time passed by. Thus, considering the same reaction conditions, the longer reaction time, the greater $\mathrm{DH}$ degree of hydrolysis, as confirmed in our study (DH was tested at $\mathrm{pH} 6.5$ for 5 hours). However, if the hydrolysis time exceeds 5 hours, this will provide microbiological contamination of milk (CONTRERAS et al., 2011).

\subsection{Antioxidant activity evaluation of caprine casein hydrolysates}

The effect of reaction time and enzyme: substrate ratio (E: S) on antioxidant activity is shown in Table 2. The investigated parameters showed no significant effects on antioxidant activity considering peptide pool. On the other hand, considering only peptides present in the permeate $(<3000 \mathrm{Da})$, the parameters time and E:S quadratic ratio were negative, being the most significant on the antioxidant activity. It was also observed that intermediate levels of time and E: S ratio enhanced the antioxidant activity. This parameter was negative therefore we obtained a concave downward graph.

The investigation of time and E: S influence on the antioxidant activity of retentate $(>3000 \mathrm{Da})$ peptides showed that linear and quadratic $\mathrm{E}: \mathrm{S}$ had opposite effects on the antioxidant activity; while linear E:S relation was positive, the quadratic effect E:S relation was negative. Moreover, it was observed that shorter reaction times and higher $\mathrm{E}: \mathrm{S}(\mathrm{Q})$ ratios led to increases in antioxidant activities. However, this statement is only correct up to intermediate time and E:S, which gave higher biological activities. Thus, we can assert that antioxidant power in 1:100 E:S ratio was lower than in 1:200 E:S ratio, considering $3 \mathrm{~h}$ time reaction. Our results differed from Morais et al. (2002) who reported that E:S ratio influences bovine casein hydrolysis by papain use. They demonstrated that an modification in the E:S ratio from $2 \%$ to $4 \%$ is responsible for the decrease in dipeptide and tripeptide levels as well as the increase in free amino acids content and oligopeptides. The latter peptide is the main responsible for biological activities. Thus, this situation prevents the use of these hydrolysates in industrial scale, since it would be necessary to increase the amount of enzyme in order to obtain peptides with functional or bioactive properties, which would increase the production cost.
Results of peptides antioxidant activity, obtained from Moxotó goat casein hydrolysis by utilization of papain enzyme use, are listed in Table 1 . The antioxidant activity of caprine casein hydrolysates ranged between 349.2 and $2329.6 \mu$ mol. $\mathrm{L}^{-1}$ TROLOX. $\mathrm{mg}^{-1}$ peptide. The highest antioxidant power of caprine casein hydrolysates was obtained for peptides present in the permeate, after 5 hours reaction and 1:150 E: S ratio.

Casein hydrolysates from ovine and caprine have been studied owing to its antioxidant activities. Silva, Pihlanto and Malcata (2006) and Gómez-Ruiz et al. (2008) respectively reported that cheeses manufactured with goat or sheep milk using Cynara cardunculus protease and ovine casein hydrolysates by utilization of papain use are sources of peptides with biological activities, including antioxidant activity.

In our study, antioxidant activities of caprine casein hydrolysates were better than obtained by Gómez-Ruiz et al. (2008), who investigated ovine casein hydrolysates and reported up to $1630 \mathrm{mg} \cdot \mathrm{mL}^{-1}$, which is approximately equivalent to $0.1 \mu \mathrm{mol} . \mathrm{L}^{-1}$ TROLOX.mg ${ }^{-1}$ peptide. Our result was also higher than reported by Clausen, Skibsted and Stagsted (2009), $0.08 \mu \mathrm{mol} . \mathrm{L}^{-1}$ TROLOX.mg ${ }^{-1}$ peptide, when they studied bovine $\beta$-casein antioxidant activity. On the other hand, Contreras et al. (2011) achieved an antioxidant activity value of $2321 \mu \mathrm{mol} . \mathrm{L}^{-1}$ TROLOX $/ \mathrm{mg}^{-1}$ peptide after the ultrafiltration of milk protein hydrolysates, which was obtained by thermolysin enzyme, using a 3000Da membrane. This result is very similar to results found herein.

TEAC results for caprine casein peptides were compared with natural antioxidants used in food industry as additives. This comparison indicated that caprine milk peptides presented higher antioxidant capacity than some wines and antioxidant activity patterns like the BHA (3-tert-butyl-4-hydroxyanisole), a-tocopherol and $\mathrm{C}$ vitamin, which demonstrate antioxidant activity of $1000 \mu$ mol. $L^{-1}$ TROLOX. $\mathrm{mg}^{-1}$ after 6 minutes of time reaction (MILLER, 1993; LACROIX; AMIOT; BRISSON, 1983; VILLAÑO et al., 2004).

Samples were subjected to ultrafiltration technique in order to evaluate the influence of peptides molar mass molecular weight on biological activities. The analyzed peptides were present in caprine casein hydrolysates, which were obtained by papain enzyme use. Ultrafiltration technique constitutes a separation process of peptides according to molar mass molecular weight, which can be used to obtain small peptides, in order to improve the biological quality of protein hydrolysates (CARREIRA et al., 2001; CHERYAN, 1998). Most of casein biological activities are present in oligopeptides, dipeptides or tripeptides, which can be obtained through the use of an ultrafiltration membrane with a specific porosity (LACROIX; AMIOT; BRISSON, 1983). Low molar mass molecular weight peptides can be separated from high molecular weight peptides using membranes whose porosities vary from 1000 to $3000 \mathrm{Da}$ (LACROIX; AMIOT; BRISSON, 1983). Results demonstrated that antioxidant activity in peptide pool, considering the test 9 , was $1674.2 \mu \mathrm{mol} \mathrm{L}^{-1}$ TROLOX. $\mathrm{mg}^{-1}$ peptide. After ultrafiltration, nevertheless, we obtained a TEAC value of 2338.5 and $2030.9 \mu$ mol. $L^{-1}$ TROLOX. $\mathrm{mg}^{-1}$ peptide, respectively, for permeate $(<3000 \mathrm{Da})$ and retentate $(>3000 \mathrm{Da})$ peptides. Thus, it was noted that the procedure 
contributed positively to the antioxidant activity since the activity level was higher in permeate peptides ( $<3000 \mathrm{Da})$ than in retentate peptides $(>3000 \mathrm{Da})$. Lacroix, Amiot and Brisson (1983) obtained similar results. They used ultrafiltration through membranes for recovering low molar mass molecular weight bioactive products with better nutritional value, which were rich in dipeptides and tripeptides and have low antigenic character. The results presented in our study contradicted Carreira et al. (2001) which employed ultrafiltration technique for obtaining functional casein hydrolysates, these authors did not acquire satisfactory results.

Antioxidant properties of caprine casein hydrolysates under studied conditions refer to the presence of peptides rich in amino acids such as histidine, lysine, proline and tyrosine (KITTS; WEILER, 2003), which were shown in some peptides sequences after sequencing analysis by MALDI-TOF-MS/MS. Moreover, the antioxidant activity of caprine casein hydrolysates can also be related to $\mathrm{DH}$, specificity and origin of the enzyme used in the proteolytic digestion. Papain is a cysteine protease which acts specifically on basic amino acids such as lysine, arginine and histidine, inducing conformational and structural changes. Such modifications lead to the production of many peptides with bioactive properties. However, the extent of proteolysis depends on protease accessibility to peptide bonds as well as to the hydrolytic conditions (SALAMI et al., 2008).

The antioxidant activity of goat casein hydrolysates with papain is an attribute that can be used to protect biological systems against damages caused by cellular oxidative stress. Thus, protein hydrolysates with antioxidant activity can be used in the food industry to reduce oxidation reactions which lead to food spoilage. Additionally, caprine casein hydrolysates can be a source of functional substances which will carry natural antioxidants, once they do not induce toxic side effects associated with their synthetic equivalents and will also provide a nutritional value to the food. Such properties represent an additional advantage to the use of caprine casein hydrolysates rather than synthetic antioxidants (CARREIRA et al., 2001).

In vitro and in vivo studies should be undertaken in order to understand precisely the mechanism of antioxidant peptide activity which was obtained from Moxotó goat milk casein in the food industry, adding value to a regional input (milk) and will promote the development of new biopharmaceuticals for local pharmaceutical industry.
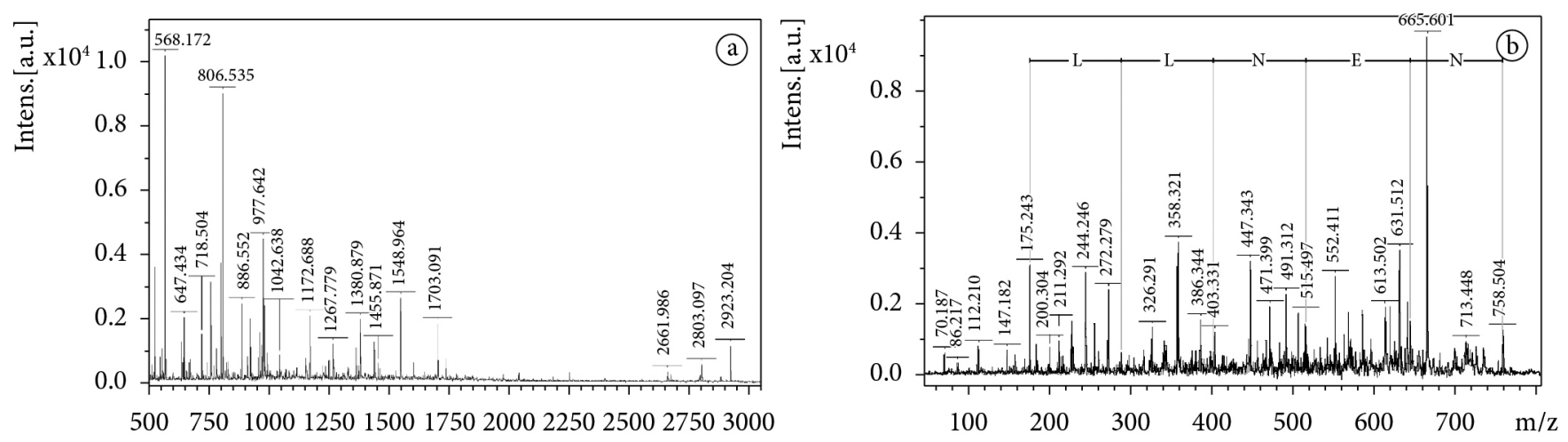

$\mathrm{m} / \mathrm{z}$
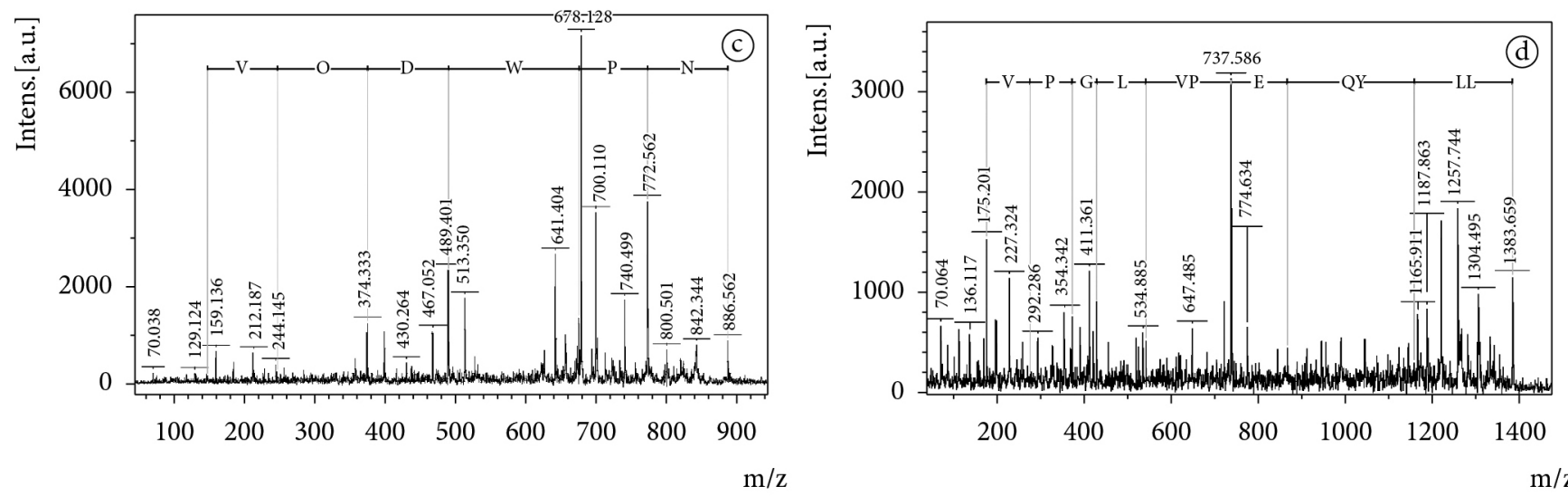

Figure 1. a) Peptide profile of Moxotó caprine casein hydrolysates from the permeate ( $<3000 \mathrm{Da}), 28.5 \% \mathrm{DH}$ of degree of hydrolysis, obtained by MALDI-TOF-MS $\backslash$ MS mass spectrometry; b) MS/MS fragmentation spectrum of 755Da molar mass molecular weight peptide; c) MS/MS fragmentation spectrum of 886Da molar mass molecular weight peptide; and d) MALDI TOF-MS/MS fragmentation spectrum of 1384Da molar mass molecular weight peptides by Flex Analysis software (BRUKER, Daltonics). 
Table 3. Molecular weights of peptides from caprine casein hydrolysates (29\% DH), obtained by papain use, which were identified in permeate and retentate fractions. The molar mass molecular weights (in bold) were identified in specific literature for presenting biological and functional properties.

\begin{tabular}{|c|c|}
\hline Fraction & Molecular mass of peptides \\
\hline Permeate & 550*; 568; 524; 638; 647; 656; 672; 718; 727; 759; 806; 887; 970; 977; 1173; 1268; 1441; 1548; 1703; 2662; 2803; 2923; \\
\hline Retentate & $2802 ; 3680 ; 3833 ; 3964,4051 ; 4110 ; 4188 ; 4464 ; 4667 ; 4862 ; 4989$ \\
\hline
\end{tabular}

\subsection{Peptide profile and amino acids sequencing from casein hydrolysates by MALDI-TOF-MS $\backslash M S$}

Caprine casein peptide profile was achieved by ultrafiltration technique using goat casein hydrolysates obtained by papain enzyme use. For the purpose of peptide profile investigation, we used samples from permeate $(<3000 \mathrm{Da})$ and retentate $(>3000 \mathrm{Da})$ with the highest $\mathrm{DH}(28.3 \%)$ and high antioxidant activity. Hydrolysates peptide profiles were compared with those available in the literature in order to predict their biological properties. In the permeate, 22 peptides were detected (Figure 1a). Among them, 12 were previously described as presenting biological and functional properties according to Zhang et al. (2011) and Sabeena Farvin et al. (2010). On the other hand, only 11 peptides were observed in the retentate (not shown data) of which none was described as owning biological properties (Table 3 ).

Peptide molar mass molecular weight, obtained by mass spectrometry (MALDI TOF-MS $\backslash$ MS), was used to predict bioactive properties of peptides which were found in the permeate in accordance with the available literature. Peptides with 550 and 647 Da molar mass molecular weight corresponded, respectively, to $f(61-65)$ and $f(61-66)$ of $\kappa$-casein fragments. These fractions are related to YAKPA and YAKPVA sequences which have antioxidant properties (GÓMEZ-RUIZ et al., 2008; SABEENA FARVIN et al., 2010). The 656 Da peptide is correspondent to the one described by Gómez-Ruiz et al. (2008) which has antihypertensive and antimicrobial properties. These authors analyzed the peptide profile of sheep casein hydrolysates by HPLC-MS $\backslash$ MS. We also obtained a 672 Da peptide, previously described by Gómez-Ruiz et al. (2008), which has [GLDIQK] sequence and is known by its antihypertensive properties. Another one was a 760 Da peptide, described by Santillo et al. (2009) who characterized it as a $\mathrm{f}(205-223)$ as ${ }_{2}$-casein, whose sequence is [K.AMKPWTQPKTNAIPYVRY]. These authors determined its antihypertensive property.

In this study, some peptides such as $760,806,887$ and 970 $\mathrm{Da}$, which were identified in permeate obtained by papain hydrolysis using $\mathrm{pH}$ 6.5, E:S 1:150 ratio and 5 hours time reaction conditions, were previously described by presenting functional properties (ALLI et al., 1998). However, these hydrolysates were obtained from cheese casein (ALLI et al., 1998), differently from our study, which used milk casein.

Another peptides detected in our study were 887, 970 and $978 \mathrm{Da}$, earlier obtained by Saito et al. (2000), Gómez-Ruiz, Ramos and Recio (2004) and Gómez-Ruiz et al. (2008) from bovine casein hydrolysates. These peptides demonstrated antihypertensive and antioxidant characteristics. Furthermore, we obtained a 1268 Da peptide, also detected by GómezRuiz et al. (2008), who evidenced its antioxidant properties. Its sequence was correspondent to [INNQFLPYPY] casein fraction.

The 759 Da peptide sequence (Figure 1b) was [NENLL], which corresponded to $\mathrm{f}(17-21)$ of $\alpha_{\mathrm{s} 1}$-casein fraction. It was previously identified by Alli et al. (1998) who also reported others $\alpha_{s 1}$-casein peptides sequences such as QEVLNE, NLLRF, NENLL and NENLLRF. These peptides are responsible for cheddar cheese flavor and its functional properties, and can be obtained from HPINHQGLSPEVPNENLL sequence, which constitutes a part of goats $\alpha_{\mathrm{S} 1}$-casein $\mathrm{f}(1-23)$ fraction. Hill, Lahav and Givol (1974) identified antimicrobial, immunomodulatory and antihypertensive properties related to peptides from $\alpha_{\mathrm{S} 1}$-casein $\mathrm{f}(1-23)$ fraction.

An 886 Da peptide presented the [NPWDQVK] sequence, which is relative to $\alpha_{\mathrm{s} 2}$-casein $\mathrm{f}(123-129)$ fraction (Figure 1c). Saito et al. (2000) and Gómez-Ruiz, Ramos and Recio (2004) obtained casein peptides with similar molar mass molecular weight; nevertheless, they registered no antioxidant effect, as described in our study. They noted, however, antihypertensive properties.

In this study, we obtained the sequence [LLYQEPVLGPV] for 1384 Da peptide (Figure 1d) which corresponded to $\beta$-casein $\mathrm{f}(191-206)$ fraction. These results were similar to Silva et al. (2012), Contreras et al. (2009) and Alli et al. (1998) when investigated the peptide profile of bovine casein in "coalho" cheese, ovine casein and bovine casein from cheddar cheese, respectively.

\section{Conclusions}

Our results allowed establishing the best conditions for Moxotó goat milk hydrolysis by papain enzyme use. Ultrafiltration treatment proved to be an effective technique for separation of peptides with antioxidant power, compatible with natural antioxidants, such as $C$ vitamin and $\alpha$-tocopherol. Peptide profile and sequencing evidenced the peptide antioxidant properties owing to specific amino acids such as histidine, lysine, proline and tyrosine, which enable its application in functional foods production and food preservation additives.

\section{Acknowledgements}

We are grateful to CAPES, CNPq, FACEPE and Faculdade São Miguel for financial support. We thank CETENE for MALDI TOF-MS analysis. 


\section{References}

ALLI, I. et al. Identification of Peptides in Cheddar Cheese by Electrospray Ionization Mass Spectrometry. International Dairy Journal, v. 8, n. 7, p. 643-649, 1998. http://dx.doi.org/10.1016/ S0958-6946(98)00097-1

BIASUTTI, E. A. et al. Action of pancreatin in obtaining protein hydrolysates with high whey oligopeptide. Brazilian Journal of Pharmaceutical Sciences, v. 44, n. 1, p. 51-60, 2008.

BIRKEMO, G. A. et al. Antimicrobial activity of two peptides casecidin 15 and 17, found naturally in bovine colostrum. Journal of Applied Microbiology, v. 106, n. 1, p. 233-240, 2008. http://dx.doi. org/10.1111/j.1365-2672.2008.03996.x

BRUNS, R. E.; SCARMINIO, I. S.; NETO BARROS. B. Statistical Design-Chemometrics. Amsterdam: Elsevier, 2006.

CARREIRA, R. L. et al. Otimização na Produção de Di- e Tripeptídeos em Hidrolisados de Caseína pela Associação de Enzimas: Pepsina, Tripsina e Subtilisina. Brazilian Journal of Food Technology, v. 4, p. 103-108, 2001.

CAVALLI, S. V. et al. Hydrolysis of caprine and ovine milk proteins, brought about by aspartic peptidases from Silybum marianum flowers. Food Chemistry, v. 106, p. 997-1003, 2008. http://dx.doi. org/10.1016/j.foodchem.2007.07.015

CENTENARO, G. S.; PRENTICE-HERNÁNDEZ, C.; SALASMELLADO, M. Efeito da concentração de enzima e de substrato no grau de hidrólise e nas propriedades funcionais de hidrolisados proteicos de corvina (Micropogonias furnieri). Química Nova, v. 32, n. 7, p. 1792-1798, 2009. http://dx.doi.org/10.1590/S010040422009000700021

Chataud, J.; DESREumeuX, S.; CARTWRIGHT, T. Procédé de fabrication dun hydrolysat enzymatique de proteins riche en di- et tri-peptides, utilizable notamment en nutrition artificielle et en dietétique. Neuilly-sur-Seine: France: Laboratorio Roger Bellon, 1988.

CHERYAN, M. Ultrafiltration and microfiltration handbook. Lancaster: Technomic Publishing, 1998. 527 p.

CHICÓN, R. et al. Antibody binding and functional properties of whey protein hydrolysates obtained under high pressure. Food Hydrocolloids, v. 23, n. 3, p. 593-599, 2009. http://dx.doi. org/10.1016/j.foodhyd.2008.04.001

CLARK, S.; SHERBON, J. W. Genetic variants of alpha(s1)-CN in goat milk:breed distribution and associations with milk composition and coagulation properties. Small Ruminant Research, v. 32, n. 2, p. 135-143, 2000. http://dx.doi.org/10.1016/S0921-4488(00)00153-X

CLAUSEN, M. N. R.; SKIBSTED, L. H.; STAGSTED, J. J. Characterization of major radical scavenger species in bovine milk through size exclusion chromatography and functional assays. Journal of Agricultural and Food Chemistry, v. 57, n. 7, p. 2312-2319, 2009. http://dx.doi.org/10.1021/jf803449t

CONTRERAS, M. M. et al. Novel casein-derived peptides with antihypertensive activity. International Dairy Journal, v. 19, n. 10, p. 566-573, 2009. http://dx.doi.org/10.1016/j.idairyj.2009.05.004

CONTRERAS, M. M. et al. Production of antioxidant hydrolysates from a whey protein concentrate with thermolysin: Optimization by response surface methodology. LWT - Food Science and Technology, v. 44, p. 9-15, 2011. http://dx.doi.org/10.1016/j. lwt.2010.06.017

EGITO, A. S. et al. Método eletroforético rápido para detecção da adulteração do leite caprino com leite bovino. Arquivo Brasileiro de Medicina Veterinária e Zootecnia, v. 58, n. 5, p.932-939, 2006. http://dx.doi.org/10.1590/S0102-09352006000500032
GHOSH, S. Physicochemical and conformational studies of papain/ sodium dodecyl sulfate system in aqueous medium. Colloids Surf A: Physicochem and Engineering Aspects, v. 264, n. 6, 2005.

GÓMEZ-RUIZ, J. Á. et al. Antioxidant activity of ovine casein hydrolysates. Identification of active peptides by HPLC-MS/MS. European Food Research and Technology, v. 227, p. 1061-1067, 2008. http://dx.doi.org/10.1007/s00217-008-0820-3

GÓMEZ-RUIZ, J. Á; RAMOS, M.; RECIO, I. Angiotensin converting enzymeinhibitory activity of peptides isolated from Manchego cheese. Stability under simulated gastrointestinal digestion. International Dairy Journal, v. 14, n. 12, p. 1075-1080, 2004. http:// dx.doi.org/10.1016/j.idairyj.2004.04.007

HAENLEIN, G. F. W. Goat milk in human nutrition. Small Ruminant Research, v. 51, n. 1, p. 155-163, 2004. http://dx.doi.org/10.1016/j. smallrumres.2003.08.010

HILL, R. D.; LAHAV, E.; GIVOL, D. A rennin-sensitive bond in alpha-s1 B-casein. Journal of Dairy Research, v. 41, n. 1, p. 147-153, 1974. http://dx.doi.org/10.1017/S0022029900015028

HORWITZ, W. (Ed.). Official methods of analysis of AOAC International. 17. ed. Gaithersburg: AOAC international, 2000.

KITTS, D. D.; WEILER, K. A. Bioactive proteins and peptides from food sources. Applications bioprocesses used in isolation and recovery. Current Pharmaceutical Design, v. 9, n. 16, p. 1309-1323, 2003. http://dx.doi.org/10.2174/1381612033454883

LACROIX, M.; AMIOT, J.; BRISSON, G. J. Hydrolysis and ultrafiltration treatment to improve the nutritive value of rapheseed protein. Journal of Food Science, v. 48, n. 6, p. 1644-1645, 1983. http:// dx.doi.org/10.1111/j.1365-2621.1983.tb05050.x

LI, Z.Y.; YOURAVONG, W.; H-KITTIKUN, A. Protein hydrolysis by protease isolated from tuna spleen by membrane filtration: a comparative study with commercial proteases. LWT - Food Science and Technology, v. 43, n. 1, p. 166-172, 2010. http://dx.doi. org/10.1016/j.lwt.2009.07.002

LIRA, T. B. F. et al. Avaliação de variáveis que influenciam a hidrólise enzimática da caseína do leite de cabra Moxotó. Pesquisa Agropecuária Brasileira, v. 45, n. 9, p. 1036-1043, 2010. http:// dx.doi.org/10.1590/S0100-204X2010000900014

LOWRY, O. H. et al. Protein measurement with the Folin phenol reagent. Journal of Biological Chemistry, v. 193, n. 1, p. 265-275, 1951.

MILLER, N. J. A novel method for measuring antioxidant capacity and its application to monitoring the antioxidant status in premature neonates. Clinical Science, v. 84, n. 4, p. 407-412, 1993.

MORAIS, H. A. et al. Caracterização do perfil peptídico e de aminoácidos em hidrolisados de caseína. Archivos latinoamericanos de nutrición, v. 52, n. 1, p. 77-83, 2002.

OLALLA, M. et al. Nitrogen fractions of Andalusian goat milk compared to similar types of commercial milk. Food Chemistry, v. 113 , n. 3, p. $835-838,2009$. http://dx.doi.org/10.1016/j. foodchem.2008.10.022

RE, R. et al. Antioxidant activity applying an improved ABTS radical cation decolorization assay. Free Radical Biology and Medicine, v. 26, n. 9-10, p. 1231-1237, 1998. http://dx.doi.org/10.1016/S08915849(98)00315-3

ROSSINI, K. et al. A. Casein peptides with inhibitory activity on lipid oxidation in beef homogenates and mechanically deboned poultry meat. LWT - Food Science and Technology, v. 42, n. 4, p. 862-867, 2009.

SABEENA FARVIN, K. H. et al. Antioxidant activity of yoghurt peptides: part 2 - characterisation of peptide fractions. Food 
Chemistry, v. 123, n. 4, p. 1090-1097, 2010. http://dx.doi. org/10.1016/j.foodchem.2010.05.029

SAITO, T. et al. Isolation and structural analysis of antihypertensive peptides that exist naturally in Gouda cheese. Journal of Dairy Science, v. 83, n. 7, p. 1434-1440, 2000. http://dx.doi.org/10.3168/ jds.S0022-0302(00)75013-2

SALAMI, M. et al. Kinetic characterization of hydrolysis of camel and bovine milk proteins by pancreatic enzymes. International Dairy Journal, v. 18, n. 12, p. 1097-1102, 2008. http://dx.doi.org/10.1016/j. idairyj.2008.06.003

SANTILLO, A. et al. Role of indigenous enzymes in proteolysis of casein in caprine milk. International Dairy Journal, v. 19, n. 11, p. 655-660, 2009.

SHOU-WEI, Y. et al. Effects of limited enzymatic hydrolysis with trypsin on the functional properties of hemp (Cannabis sativa L.) protein isolate. Food Chemistry, v. 106, n. 3, p. 1004-1013, 2008.

SILVA, F. L. R.; ARAÚJO, M. R. A. Desempenho produtivo em caprinos mestiços no semi-árido do Nordeste do Brasil. Revista Brasileira de Zootecnia, v. 29, p. 1028-1035, 2000. http://dx.doi.org/10.1590/ S1516-35982000000400012

SILVA, R. A. et al. Can artisanal "Coalho" cheese from Northeastern Brazil be used as a functional food? Food Chemistry, v. 135, n. 3, p. 1533-1538, 2012. http://dx.doi.org/10.3168/jds.S00220302(06)72370-0
SILVA, S. V.; PIHLANTO, A.; MALCATA, X. F. Bioactive Peptides in Ovine and Caprine Cheeselike Systems Prepared with Proteases from Cynara cardunculus. Journal of Dairy Science, v. 89, n. 9, p. 3336-3344, 2006.

STATSOFT. Statistica: data analysis software systems version 8.0. 2008.

VILLAÑO, D. et al. The antioxidant activity of wines determined by the ABTS(+) method: influence of sample dilution and time. Talanta, v. 64, n. 2, p. 501-509, 2004. http://dx.doi.org/10.1016/j. talanta.2004.03.021

ZHANG, L.; LI, J.; ZHO, U. K. Chelating and radical scavenging activities of soy protein hydrolysates prepared from microbial proteases and their effect on meat lipid peroxidation. Bioresource Technology, v. 101, n. 7, p. 2084-2089, 2009. http://dx.doi. org/10.1016/j.biortech.2009.11.078

ZHANG, Q. et al. Influence of casein hydrolysates on the growth and lactic acid production of Lactobacillus delbrueckii subsp. bulgaricus and Streptococcus thermophilus. International Journal of Food Science Technology, v. 46, n. 5, p. 1014-1020, 2011. http://dx.doi. org/10.1111/j.1365-2621.2011.02578.x

ZHAO, X. H.; WU, D.; LI, T. J. Preparation and radical scavenging activity of papain-catalyzed casein plasteins. Dairy Science and Technology, v. 90, n. 5, p. 521-535, 2010. http://dx.doi.org/10.1051/ dst $/ 2009054$ 